\title{
Effects of Short-Term Exposure to Dispersed Oil in Arctic Invertebrates
}

\author{
C. MAGEAU, ${ }^{1}$ F.R. ENGELHARDT, ${ }^{2}$ E.S. GILFILLAN ${ }^{3}$ and P.D. BOEHM ${ }^{4}$
}

(Received 5 July 1986; accepted in revised form 14 May 1987)

\begin{abstract}
A series of experimental studies was carried out as part of the Baffin Island Oil Spill (BIOS) Project to define the behavioural, physiological and biochemical reactions of three arctic marine benthic invertebrate species exposed to chemically dispersed crude oil. Behavioural responses and patterns of hydrocarbon accumulation and release observed in the bivalves and the urchin during the 1981 field spill were similar to those observed during the laboratory simulations. Ostial closure, loss of responsiveness to mechanical stimuli and narcosis were characteristic of the bivalves. Exposed urchins displayed a functional loss of tube foot and spine behaviour. Detailed hydrocarbon analysis indicated different uptake dynamics among the species. The effects of dispersed oil were immediate and short lived and resulted in temporary accumulation of hydrocarbons.

Depuration of these stored hydrocarbons occurred during the experimental recovery period. In vivo biodegradation of hydrocarbons was indicated in the bivalves. Physiological parameters measured in bivalves exposed to oil included elements of scope for growth, activity of aspartate aminotransferase and glucose-6-phosphate dehydrogenase. Dose-response relationships between physiological rates and hydrocarbon body burden were apparent.
\end{abstract}

Key words: petroleum effects, Arctic, invertebrates, metabolism, enzymes, behaviour, biodegradation, hydrocarbon uptake, Baffin Island oil spill, dispersant

RÉSUMÉ. Une série d'études expérimentales ont été effectuées dans le cadre du projet de déversement de pétrole à l'île Baffin (BIOS), afin de définir les modifications du comportement, ainsi que les réactions physiologiques et biochimiques de trois espèces d'invertébrés marins du benthos exposés à du pétrole brut dispersé chimiquement. Les comportements et les formes d'accumulation des hydrocarbures observés sur place, pendant le déversement de 1981, étaient semblables à ceux observés lors de simulations en laboratoire. La fermeture de l'ostium, la perte de réaction à des stimuli mécaniques et la narcose étaient des réactions caractéristiques des bivalves. Les oursins exposés au pétrole montraient une perte fonctionnelle de réaction de l'ambulacre et des piquants. Une analyse approfondie des hydrocarbures a révélé une dynamique d'absorption différente selon les espèces.Les effets du pétrole dispersé étaient immédiats et de courte durée, et ils avaient pour résultat une accumulation temporaire d'hydrocarbures.

Le rejet de ces hydrocarbures accumulés s'est produit pendant la période de récupération expérimentale. Une biodécomposition in vivo des hydrocarbures s'est manifestée chez les bivalves.

Les paramètres physiologiques mesurés chez les bivalves exposés au pétrole comprenaient des éléments de la gamme de croissance, l'activité de la transaminase glutamo-oxaloacétique et de la glucose-6-phosphate déhydrogénase. On a observé des rapports manifestes de dose à réponse entre les taux physiologiques et la charge corporelle en hydrocarbures.

Mots clés: effets dus au pétrole, Arctique, invertébrés, métabolisme, enzymes, comportement, biodécomposition, absorption d'hydrocarbures, projet de déversement de pétrole à l'île Baffin, agent de dispersion

Traduit pour le journal par Nésida Loyer.

\section{INTRODUCTION}

While chemical dispersion of spilled oil has been used as a routine countermeasure in some parts of the world to protect biologically sensitive nearshore environments, there was little information available to evaluate the effectiveness and impact of dispersant use under arctic conditions. The Baffin Island Oil Spill (BIOS) Project was designed to address this problem. The biological and geochemical fate as well as the toxicity effects were monitored in both a chemically dispersed spill and an untreated surface spill (Sergy and Blackall, 1987).

The field studies were successful in differentiating the shortterm effects of the dispersed oil spill from that of the untreated oil discharge, as described in other papers in this volume. However, the original BIOS field program was not designed to monitor the behaviour or physiology of the biota exposed to the spills in a controlled fashion. Similarly, field logistics could not provide the temporal consistency required to define the dynamics of hydrocarbon uptake and release in the affected biota. This study was carried out to define better the short-term effects of hydrocarbon exposure on biologically important benthic organisms from the arctic environment at Cape Hatt and to evaluate their behavioural and metabolic responses. Selection of the test organisms was based on their relative abundance, their impor- tance in the Cape Hatt benthic community and their documented sensitivity to the 1981 spill (Cross and Thomson, 1981). To maximize consistency between the original BIOS spill and the laboratory simulations, the study was conducted at the BIOS site using the same key species examined in the field spill and an exposure protocol indicated by the water chemistry data recorded in the immediate post-spill period (Green et al., 1982; Humphrey et al., 1987). Concurrent studies on the behavioural, physiological and biochemical impacts over a range of additional oil exposure regimes are detailed elsewhere (Mageau and Engelhardt, 1984; Gilfillan and Vallas, 1984; Engelhardt et al., 1984).

\section{MATERIALS AND METHODS}

The study was carried out from August through September of 1982 and 1983 at Cape Hatt on northern Baffin Island at the site of the 1981 BIOS experimental spills (Sergy and Blackall, 1987). The field laboratory was situated on Eclipse Sound, N.W.T. $\left(72^{\circ} 28^{\prime} \mathrm{N}, 79^{\circ} 50^{\prime} \mathrm{W}\right)$ on the shore of one of the bays remote from the main spill site. The study was designed to duplicate normal physical and chemical characteristics of the spill area to the degree possible, while imposing a greater degree of control over experimental variables.

\footnotetext{
${ }^{1}$ Northern Environment Directorate, Indian and Northern Affairs, Les Terrasses de la Chaudière, Ottawa, Ontario, Canada K1A 0H4

${ }^{2}$ Canada Oil and Gas Lands Administration, 355 River Road, Ottawa, Ontario, Canada K1A 0E4

${ }^{3}$ Bowdoin College, Marine Research Laboratory, Brunswick, Maine 04011, U.S.A.

${ }^{4}$ Battelle Ocean Sciences, 397 Washington Street, Duxbury, Massachusetts 02332, U.S.A.

(C)The Arctic Institute of North America
} 


\section{Experimental Design}

A flow-through system was constructed on-site using a battery of $50 l$ aquaria with a continuous flow of sea water of 100 $\mathrm{ml} \cdot \mathrm{min}^{-1}$ per tank. Sea water was drawn from an offshore intake at an $8 \mathrm{~m}$ water depth where tidal effects were minimal (Buckley et al., 1987). The flow-through system was temporarily interrupted in experimental and control tanks during exposure to oil, and individual circulating pumps were used to recirculate the total water volume to ensure continued and uniform exposure. Controls for each species were monitored concurrently. In 1982, both covered and uncovered tanks were used to compare potential losses of volatile fractions. Although this loss was not significant, in 1983 all tanks were covered with sheet glass during the dosing period. Temperature and salinity were measured regularly throughout the experimental period and were found (as means \pm S.D.) to be $4^{\circ} \pm 1^{\circ} \mathrm{C}$ and $24 \% \circ \pm 3 \%$ in 1982 and $6^{\circ} \pm 1^{\circ} \mathrm{C}$ and $26 \% \pm 3 \%$ in 1983 . These conditions were in the range of temperatures and salinities recorded in the offshore water where the test species were collected. Natural but subdued lighting in the holding facility was maintained.

Of the three test species, two were filter-feeding bivalves, Mya truncata and Serripes groenlandicus, and the other a surface deposit feeder, the green sea urchin Strongylocentrotus droebachiensis. The animals were hand collected by divers in the waters of Milne Inlet at a depth of $7 \mathrm{~m}$ off the western shore of Ragged Island. This site was situated near Cape Hatt but in an area removed from the 1981 experimental spill. The test animals were held in the flow-through sea water system for at least 7 days prior to the exposure studies. Mortalities during this acclimation period were less than $3 \%$. Fresh seaweed (Laminaria sp.) and broken shell material were supplied regularly to the urchins during the pre-exposure period. $S$. groenlandicus was kept in a $10 \mathrm{~cm}$ layer of sifted and washed medium-grain beach sand, while both $M$. truncata and $S$. droebachiensis were held without sediment. During both years, test animals were of a medium-size range for each species: $M$. truncata were $4.3 \pm 0.4 \mathrm{~cm}, S$. groenlandicus $4.3 \pm 0.6 \mathrm{~cm}$, and urchins $4.6 \pm 0.6 \mathrm{~cm}$. Holding densities in 1982 and 1983 were calculated not to exceed natural densities as identified in Cross and Thomson (1981).

\section{Exposure Protocol}

Dispersed oil concentrations were prepared by dilution of a stock oil/dispersant mixture. The mixture was prepared as a $25000 \mathrm{mg} \cdot \mathrm{kg}^{-1}$ suspension by vortex stirring of the BIOS-stock aged Lagomedio crude oil (Dickins et al., 1987) with Corexit-9527 (10:1) in sea water. All concentrations are expressed on a basis of weight of crude oil (Lagomedio density $\left.0.9 \mathrm{~g} \cdot \mathrm{ml}^{-1}\right)$.

The 1981 hydrocarbon data collected from the bays and depth locations monitored during the spill were integrated and suggested the $6 \mathrm{~h} / 6 \mathrm{~h} / 6 \mathrm{~h}$ dosing sequence. Hydrocarbon levels and sequences reported by Green et al. (1982) for the $18 \mathrm{~h}$ period following the dispersed oil spill of Bay 9 were reproduced by the $10 / 100 / 5 \mathrm{mg} \cdot \mathrm{kg}^{-1}$ concentration series. The $0.5 / 5.0 / 0.2 \mathrm{mg} \cdot \mathrm{kg}^{-1}$ concentration series approximated the $18 \mathrm{~h}$ post-spill levels observed in Bay 10, a site adjacent to the dispersed oil spill site. The three sequential $6 \mathrm{~h}$ dosing periods were followed by clearance periods of 7 and 21 days in 1982 and 1983 respectively.

\section{Behaviour Measurements}

The behaviour of the test species was assessed according to the methodology established by Engelhardt et al. (1983). Only those indexes judged to be both quantifiable and significant to the survival of the individual were selected (Table 1). The responses were quantified on the basis of the proportion of the test population that exhibited a specific response at the given exposure. The time required for $50 \%$ of the initial population to show a measured behaviour change was used as the standard point of comparison (ET50). Either the life habit of the test species and/or the experimental conditions precluded the assessment of all of the initial population at some time intervals. Recovery was defined as the elapsed time at which the affected

TABLE 1. Behavioural responses of Mya truncata, Serripes groenlandicus and Stronglyocentrotus droebachiensis exposed to dispersed crude oil

\begin{tabular}{|c|c|c|}
\hline Target species & $\begin{array}{l}\text { Behavioural } \\
\text { responses }\end{array}$ & Description \\
\hline $\begin{array}{c}\text { Strongylocentrotus } \\
\text { droebachiensis }\end{array}$ & $\begin{array}{l}\text { spine rigidity } \\
\text { curling of tube } \\
\text { feet } \\
\text { retraction of } \\
\text { tube feet } \\
\text { Stimulus response } \\
\text { tube feet }\end{array}$ & $\begin{array}{l}\text { detrital material, shell } \\
\text { fragments and pieces of } \\
\text { algae cover aboral surface } \\
\text { of test } \\
\text { attachment to glass of } \\
\text { aquarium floor and sides by } \\
\text { tube feet } \\
\text { depression of spines } \\
\text { downward along surface } \\
\text { of test } \\
\text { "pincushion" orientation } \\
\text { and loss of hinge flexibility } \\
\text { aboral tube feet showing } \\
\text { curling of distal ends } \\
\text { aboral tube feet not } \\
\text { protruding } \\
\text { tube foot retraction } \\
\text { following mechanical } \\
\text { stimulus laterally on test } \\
\text { re-orientation toward source } \\
\text { of mechanical stimulus } \\
\text { laterally on test }\end{array}$ \\
\hline \multirow[t]{2}{*}{ Mya truncata } & $\begin{array}{l}\text { Direct observation } \\
\text { ostial closure } \\
\text { siphon } \\
\text { retraction }\end{array}$ & $\begin{array}{l}\text { closure of both inhalent } \\
\text { and exhalent siphons } \\
\text { retraction of siphon to } 1 / 2 \text { or } \\
\text { less of normal extended } \\
\text { length }\end{array}$ \\
\hline & $\begin{array}{l}\text { Stimulus response } \\
\text { siphon }\end{array}$ & $\begin{array}{l}\text { siphon retraction following } \\
\text { mechanical stimulus to } \\
\text { siphon } \\
\text { retraction of mantle and } \\
\text { closure of shell following } \\
\text { mechanical stimulus of } \\
\text { mantle edge }\end{array}$ \\
\hline \multirow[t]{2}{*}{$\begin{array}{l}\text { Serripes } \\
\quad \text { groenlandicus }\end{array}$} & $\begin{array}{l}\text { Direct observation } \\
\text { buried } \\
\text { ostial closure } \\
\text { mantle gape }\end{array}$ & $\begin{array}{l}\text { burial to depth where ostia } \\
\text { are exposed } \\
\text { closure of one ostium or } \\
\text { both ostia } \\
\text { mantle edges not closed and } \\
\text { shell gaping }\end{array}$ \\
\hline & $\begin{array}{l}\text { Stimulus response } \\
\text { siphon }\end{array}$ & $\begin{array}{l}\text { siphon retraction following } \\
\text { mechanical stimulus to } \\
\text { siphon }\end{array}$ \\
\hline
\end{tabular}


animals returned to pre-exposure behaviour.The values for recovery time for each species and test were derived by plotting the percentage of organisms showing the index response against elapsed time on arithmetic paper.

Fisher's Exact Probability Test, a non-parametric technique for categorical (discrete) data (Siegel, 1956) with $\alpha \leq 0.05$, was performed to test the difference in ET50 and recovery time between the control group and experimental groups for each observed behaviour. The Statistical Analysis System (SAS) frequency procedure was used to calculate the significance values from the Fisher Exact Test. All statistical manipulations were analyzed on the basis of time. The plots of each control and simulation comparison generated by the SAS plotting procedure were used to generate the ET50 values.

\section{Metabolism Measures}

Samples of control and experimental $M$. truncata and $S$. groenlandicus were collected in 1983 at the onset of exposure $(\mathrm{t}=0), 18 \mathrm{~h}, 7 \mathrm{~d}$ and $14 \mathrm{~d}$ and analyzed for tissue enzyme activity and scope for growth elements.

Elements of scope for growth, assimilation, filtration, respiration rate and the activity of aspartate aminotransferase (AAT) and glucose -6-phosphate dehydrogenase (G-6-PDH) were measured for field populations, for laboratory control and experimental animals. Methods used to determine scope for growth of $S$. groenlandicus and $M$. truncata were similar to those used by Gilfillan et al. (1976). Respiration rates were measured by a Gilson Differential Respirometer following an acclimation period. Filtration rates (= clearance rates) were determined using standard culture techniques using Dunaliella tertiolecta as food source in $4 l$ containers. Initial and final concentrations of the algae were measured using a Coulter Counter, model ZBI.

Assimilation efficiency was determined from the relationship between the organic fraction ingested and that excreted. Length and dry weight of the freeze-dried animals were recorded. Differences in size between groups of experimental animals were normalized by expressing the data in terms of a "standard" animal or reference animal, since many rate functions of marine poikilotherms are known to vary logarithmically with body weight. The relationship between the logarithm of the animal's dry weight and either the volume of oxygen consumed or the volume of water filtered was used to calculate these functions for a standard animal of a specified size (Ansell and Lander, 1967; Gilfillan et al., 1977).

Scope for growth for the test animals using standard values in carbon units for respiration and filtration was calculated. A standard value of 0.85 was assumed for the animals' respiratory quotient (R.Q.), being typical for an invertebrate animal metabolizing a mixture of fat and carbohydrates. The amount of carbon respired in $\mu \mathrm{g} \cdot \mathrm{h}^{-1}$ was calculated as $0.42 \times \mu l \mathrm{O}_{2}$ consumed per hour. The physiological rates of undisturbed animals were calculated on the basis of the mean of the above physiological parameters, as measured in three wild populations and in unexposed animals used as controls during the exposure tests. They are expressed as the $t=0$, or control, rate.

The amount of carbon consumed by the animals (gross carbon) was calculated as the filtration rate of the standard animal in $l \cdot \mathrm{h}^{-1} \times 500 \mu \mathrm{g} \mathrm{C} \cdot l^{-1}$ (mean concentration of carbon in food samples). The constant for the amount of available food was equal to the concentrations observed in the test water and facilitated comparison of data among sampling dates; it did not introduce an error in interpretation. Net carbon uptake was calculated as gross carbon $\times$ assimilation ratio. Scope for growth was calculated as net carbon minus respired carbon.

The AAT and G-6-PDH enzymes were considered useful indexes because they mediate in vivo transfer of energy reserves. Animals to be used for enzyme analysis were frozen in the field within three hours of collection time. Freshly thawed tissue from two or more individuals was combined with three parts $w / v$ of ice-cold Tris/EDTA buffer solution and then ground thoroughly in a Virtis homogenizer. This preparation was centrifuged at $11000 \mathrm{~g}$ at $4^{\circ} \mathrm{C}$ and the supernatant was used as the crude enzyme extract for immediate analysis. Protein content of the extraction was determined by the Biuret test using bovine serum albumen as a standard. The extraction procedure and the method for the assay of G-6-PDH activity was derived from Gould (1977). The assay for AAT was adapted from Thurberg $e t$ al. (1977). Each enzyme assay was performed in triplicate. An exponential regression analysis was carried out to correlate metabolic data (SFG, AAT, G-6-PDH) with tissue burden of hydrocarbons.

\section{Hydrocarbon Analysis}

Sample preparation, extraction and analysis used methods similar to those of other BIOS studies (Boehm et al., 1982a,b; Cretney et al., 1987; Mageau and Engelhardt, 1984). Samples of aquarium water were taken at mid-depth at $2 \mathrm{~h}$ intervals for each exposure series. Samples of the test organisms were taken at random for tissue hydrocarbon analysis at 6 and $18 \mathrm{~h}$ during all exposure periods and at the end of each clearance period. Additional samples were taken to duplicate the 1981 field sampling scheme in the 1982 experiments at $36 \mathrm{~h}, 3 \mathrm{~d}$ and $7 \mathrm{~d}$ and in 1983 also at 21 dinto the clearance period. Water samples collected from the exposure tanks at the beginning, at $2 \mathrm{~h}$ intervals, at the end of each exposure and during the clearance period were analyzed immediately by ultraviolet (UV) fluorometry. Dispersed Lagomedio crude was used for calibration. All readings were carried out in the linear range of the fluorescence calibration, at times necessitating dilution of test samples with local sea water. Duplicate samples were found to be within $5 \%$. Analysis of hydrocarbon levels in water over the $6 \mathrm{~h}$ exposure confirmed that the real concentrations were as designed. Selected tissue samples were extracted for gas chromatographic analysis of total and fractional hydrocarbon burden. The remainder were analyzed for total hydrocarbon residues by UV fluorescence. The soft internal tissue of urchins and the visceral tissue from bivalves were removed from five individuals of each species. The tissues were pooled as a single sample for each species for each time period.

\section{RESULTS}

\section{Behavioural Responses}

An extreme sensitivity of $M$. truncata to external disturbances other than oil, probably a physical disturbance, masked the behavioural responses. Ostial closure, the most sensitive response of $M$. truncata exposed to Bay 9 simulations, was of short duration. Similarly, retraction of the siphon was only observed during the exposure period. Normal siphonal attitude resumed at the onset of the clearance period. Exposure to Bay 10 simulations did not affect the behaviour of this bivalve, and no mortality was recorded during either Bay 9 or 10 laboratory simulations (Table 2). 
TABLE 2. Behavioural responses of Mya truncata, Serripes groenlandicus and Strongylocentrotus droebachiensis exposed to crude oil dispersions in sequences of three exposure levels

\begin{tabular}{|c|c|c|c|c|}
\hline \multicolumn{5}{|l|}{ Mya truncata } \\
\hline Exposure $^{a}$ condition & Ostial closure & Siphon retraction & Stimulus response - siphon & Stimulus response \\
\hline \multicolumn{5}{|l|}{ ET50 } \\
\hline $\begin{array}{l}\text { Bay } 10 \\
\text { A. } 0.5 / 5 / 0.2 \\
\text { B. } 0.5 / 5 / 0.2\end{array}$ & $\begin{array}{l}\text { NC } \\
\text { NC }\end{array}$ & $\begin{array}{l}\text { NC } \\
\text { NC }\end{array}$ & $\begin{array}{l}\mathrm{NC} \\
-\end{array}$ & $\begin{array}{l}\mathrm{NC} \\
-\end{array}$ \\
\hline $\begin{array}{l}\text { Bay } 9 \\
\text { A. } 10 / 100 / 5 \\
\text { B. } 10 / 100 / 5\end{array}$ & $\begin{array}{l}2 \mathrm{~h} \\
1 \mathrm{~h}\end{array}$ & $\begin{array}{r}6.5 \mathrm{~h} \\
7 \mathrm{~h}^{\mathrm{b}}\end{array}$ & $1 \mathrm{~d}$ & $\frac{13 \mathrm{~h}}{-}$ \\
\hline RECOVERY & & & & \\
\hline $\begin{array}{l}\text { Bay } 10 \\
\text { A. } 0.5 / 5 / 0.2 \\
\text { B. } 0.5 / 5 / 0.2\end{array}$ & $\begin{array}{l}\text { NC } \\
\text { NC }\end{array}$ & $\begin{array}{l}\text { NC } \\
\text { NC }\end{array}$ & $\begin{array}{l}\mathrm{NC} \\
-\end{array}$ & $\begin{array}{l}\mathrm{NC} \\
-\end{array}$ \\
\hline $\begin{array}{l}\text { Bay } 9 \\
\text { A. } 10 / 100 / 5 \\
\text { B. } 10 / 100.5\end{array}$ & $\begin{array}{r}18 \mathrm{~h} \\
3 \mathrm{~d}\end{array}$ & $\begin{array}{r}18 \mathrm{~h} \\
1 \mathrm{~d}\end{array}$ & $5 \mathrm{~d}$ & $\frac{1 \mathrm{~d}}{-}$ \\
\hline
\end{tabular}

Serripes groenlandicus

Exposure condition Emergence

ET50

Bay 10

\begin{tabular}{|c|c|c|c|c|c|c|}
\hline A. $0.5 / 5 / 0.2$ & $15 \mathrm{~h}$ & $6 \mathrm{~h}$ & $\mathrm{NC}$ & $\mathrm{NC}$ & $\mathrm{NC}$ & $\mathrm{NC}$ \\
\hline B. $0.5 / 5 / 0.2$ & $13 \mathrm{~h}$ & $8.5 \mathrm{~h}$ & - & - & - & - \\
\hline \multicolumn{7}{|l|}{ Bay 9} \\
\hline A. $0.5 / 5 / 0.2$ & $14 \mathrm{~h}$ & $<1 / 2 h$ & $7 \mathrm{~h}, 2 \mathrm{~d}$ & $>0.5 \mathrm{~h}<10 \mathrm{~h}, 1 \mathrm{~d}$ & $7 \mathrm{~h}$ & $\mathrm{NC}$ \\
\hline
\end{tabular}

\section{RECOVERY}

Bay 10
A. $0.5 / 5 / 0.2$
$2 \mathrm{~d}$
$2 \mathrm{~d}$
NC
NC
NC
NC
Bay 9
A. $10 / 100 / 5$
B. $10 / 100 / 5$
$1.5 \mathrm{~d}$
$4 \mathrm{~d}$
-
$5 \mathrm{~d}$
$\leq 13 \mathrm{~h}, 7 \mathrm{~d}$
$\leq 13 \mathrm{~h}, 2 \mathrm{~d}$
$3 \mathrm{~d}$
$\mathrm{NC}$

Strongylocentrotus droebachiensis

\begin{tabular}{|c|c|c|c|c|c|c|c|c|c|}
\hline $\begin{array}{l}\text { Exposure }^{a} \\
\text { condition }\end{array}$ & $\begin{array}{l}\text { Loss of } \\
\text { cover }\end{array}$ & $\begin{array}{c}\text { Loss of } \\
\text { attachment ability }\end{array}$ & $\begin{array}{l}\text { Spine } \\
\text { droop }\end{array}$ & $\begin{array}{l}\text { Spine } \\
\text { rigidity }\end{array}$ & $\begin{array}{l}\text { Curling of } \\
\text { tube feet }\end{array}$ & $\begin{array}{l}\text { Retraction of } \\
\text { tube feet }\end{array}$ & $\begin{array}{c}\text { Stimulus response } \\
\text { - tube feet }\end{array}$ & $\begin{array}{c}\text { Stimulus response } \\
\text { — spines }\end{array}$ & Lethality \\
\hline
\end{tabular}

ET50

Bay 10

\begin{tabular}{|c|c|c|c|c|c|c|c|c|c|}
\hline $\begin{array}{l}\text { A. } 0.5 / 5 / 0.2 \\
\text { B. } 0.5 / 5 / 0.2\end{array}$ & $\stackrel{\mathrm{NC}}{-}$ & $\begin{array}{l}9 \mathrm{~h} \\
7 \mathrm{~h}\end{array}$ & $\begin{array}{l}7 \mathrm{~h} \\
9 \mathrm{~h}^{\mathrm{b}}\end{array}$ & $\begin{array}{l}<4 \mathrm{~h} \\
\mathrm{NC}\end{array}$ & $\begin{array}{l}2 \mathrm{~h} \\
\mathrm{NC}\end{array}$ & $\begin{array}{l}13 \mathrm{~h} \\
11 \mathrm{~h}\end{array}$ & $\frac{7 \mathrm{~h}}{-}$ & $\frac{7 \mathrm{~h}}{-}$ & NC \\
\hline Bay 9 & & & & & & & & & \\
\hline $\begin{array}{l}\text { A. } 10 / 100 / 5 \\
\text { B. } 10 / 100 / 5\end{array}$ & $\begin{array}{r}6 \mathrm{~h} \\
1.5 \mathrm{~h}\end{array}$ & $\begin{array}{c}<0.5 \mathrm{~h} \\
\mathrm{NC}\end{array}$ & $\begin{array}{r}1 \mathrm{~h} \\
11 \mathrm{~d}\end{array}$ & $\begin{array}{c}0.5 \mathrm{~h} \\
\mathrm{NC}\end{array}$ & $\begin{array}{r}1 \mathrm{~h} \\
<2 \mathrm{~h}\end{array}$ & $3 \mathrm{~h}$ & $\underline{2 \mathrm{~h}}$ & $\frac{2 \mathrm{~h}}{-}$ & $\frac{\mathrm{NC}}{-}$ \\
\hline
\end{tabular}

\section{RECOVERY}

Bay 10

\begin{tabular}{|c|c|c|c|c|c|c|c|c|c|}
\hline $\begin{array}{l}\text { A. } 0.5 / 5 / 0.2 \\
\text { B. } 0.5 / 5 / 0.2\end{array}$ & $\begin{array}{l}4 \mathrm{~d} \\
3 \mathrm{~d}^{\mathrm{b}}\end{array}$ & $\begin{array}{l}11 \mathrm{~h} \\
14 \mathrm{~h}\end{array}$ & $15 \mathrm{~h}$ & $\begin{array}{l}15 \mathrm{~h} \\
\mathrm{NC}\end{array}$ & $\begin{array}{l}>1 d \\
>14 d\end{array}$ & $\begin{array}{c}18 \mathrm{~h} \\
-\end{array}$ & $\frac{16 \mathrm{~h}}{-}$ & $\frac{13 \mathrm{~h}}{-}$ & $\begin{array}{l}\text { NC } \\
\text { NC }\end{array}$ \\
\hline \multicolumn{10}{|l|}{ Bay 9} \\
\hline $\begin{array}{l}\text { A. } 10 / 100 / 5 \\
\text { B. } 10 / 100 / 5\end{array}$ & $\begin{array}{l}>7 \mathrm{~d} \\
10 \mathrm{~d}\end{array}$ & $\begin{array}{l}>7 d \\
N C\end{array}$ & $\begin{aligned} & 5 d \\
> & 14 d\end{aligned}$ & $\begin{array}{l}>5 \mathrm{~d} \\
\mathrm{NC}\end{array}$ & $\begin{array}{l}>6 d \\
14 d\end{array}$ & $\begin{array}{l}6 \mathrm{~d} \\
-\end{array}$ & $\begin{array}{l}6 \mathrm{~d} \\
-\end{array}$ & $\begin{array}{c}\geq 2 \mathrm{~d}, \leq 6 \mathrm{~d} \\
-\end{array}$ & $\begin{array}{l}\mathrm{NC} \\
-\end{array}$ \\
\hline
\end{tabular}

a $18 \mathrm{~h}$ of exposure to Lagomedio crude oil dispersions, given in three sequential concentrations of $6 \mathrm{~h}$ each, followed by 7 or $21 \mathrm{~d}$ of post-exposure observation; numerical entries identify concentration; all concentrations in $\mathrm{mg} \cdot \mathrm{kg}^{-1}$.

NC - No change from control or maximum less than $20 \%$ of starting test population.

$-=$ No data due to inaccessibility of animals because of covered system or to inability to observe behavioural change in submerged animals or in dispersionclouded water.

b Indicates that maximum response was shown by less than $50 \%$ of starting population, generally $20-40 \%$.

A - 1982 data.

B - 1983 data; no stimulus data including confirmation of lethality recorded because tanks were continuously covered.

ET50 - Time from start of exposure at which one-half of the starting test population showed the index response. 
Ostial closure and siphon retraction in $S$. groenlandicus occurred almost immediately after exposure. Forceful closure of valves and marginal shell surface damage were characteristic responses to the Bay 9 simulations. The shell damage resulted from tight apposition of the valves and included pinching of the extruded foot. These responses were observed less frequently during the Bay 10 simulation. Emergence from sediment, temporary narcosis and gaping of the mantle were noted for $S$. groenlandicus during both simulations (Table 2). Biphasic responses were noted for mantle gape and foot protrusion during the Bay 9 simulation. The second onset of the behavioural response was latent, occurring after the exposure period.

Longer delays in recovery and reburial times occurred in the Bay 9-type exposure than in the Bay 10 simulation. The Bay 9 exposure also resulted in an increased locomotion in $S$. groenlandicus. Saltatory locomotion occurred when the extended foot contacted the sediment and straightened rapidly to propel the bivalve through the water. This locomotion was noted in those animals that were at the sediment surface at the onset of the exposure, as well as in previously buried animals during the latter phases of the sequential exposure. Locomotion was only rarely observed during the pre-exposure period. No lethality was recorded in either Bay 9 or Bay 10 simulations.

Strongylocentrotus droebachiensis displayed a broad range of behavioural responses. An apparent impairment of tube foot functions resulted in the loss of covering material (Fucus sp. and shell fragments) and in an inability to remain attached to the substrate. Curling and retraction of aboral tube feet were exposure dependent and occurred earlier in the Bay 9 simulation than in the Bay 10 simulation. Recovery of all normal tube foot responses was delayed longer in the Bay 9 simulation.

Although changes in spine attitude were observed in urchins from both sequential exposures, recovery of normal spine attitude was delayed by 13 days in Bay 9 urchins as compared to Bay 10 animals. Drooping of aboral spines was noted during both the 1982 and 1983 experiments, but the pincushion effect characteristic of the "spine rigidity" index was notably absent in 1983. In general, spinal responses recovered more rapidly than tube foot responses. An additional difference in behaviour between 1982 and 1983 tests was that the 1982 simulations resulted in frequent shedding of gametes by the urchins within two days of exposure to oil. This shedding was not found to be common in controls and was not observed at all in the 1983 tests.

\section{Metabolism}

Mya truncata exposed to dispersed oil proved to be a difficult subject in which to monitor physiological effects. For example, the sensitivity of the organism to outside disturbances prevented the reliable measurement of pre-exposure respiration and assimilation rates. As a result, no post-exposure data for $M$. truncata are reported.

Serripes groenlandicus exposed to both the Bay 9 and Bay 10 simulations showed a reduction of scope for growth due to a decreased filtration rate combined with an increased respiratory loss (Table 3). Scope for growth elements had not recovered to control levels 14 days after exposure in the Bay 9 sequence. The Bay 10 animals experienced a lesser decrease in filtration and respiration activity and returned to control levels within this period. Although these elements of scope for growth were reduced following exposure, the amount of carbon available to
TABLE 3. Values of the elements of scope for growth and of activity of aspartate aminotransferase and glucose-6-phosphate dehydrogenase in Serripes groenlandicus subjected to chemically dispersed oil

\begin{tabular}{|c|c|c|c|c|c|c|}
\hline Time* & ASSIM & FILT & RESP & CFLUX & AAT & G6PDH \\
\hline \multicolumn{7}{|c|}{ Bay 9 Simulation $\left(10,100,5 \mathrm{mg} \cdot \mathrm{kg}^{-1}\right)$} \\
\hline 0 & $\begin{array}{c}71 \\
(32)\end{array}$ & $\begin{array}{l}1.05 \\
(.68)\end{array}$ & $\begin{array}{l}130 \\
(22)\end{array}$ & $\begin{array}{c}359 \\
(408)\end{array}$ & $\begin{array}{c}53.1 \\
(34.4)\end{array}$ & $\begin{array}{c}7.88 \\
(3.88)\end{array}$ \\
\hline $18 \mathrm{~h}$ & nd & $\begin{array}{c}0.000 \\
(0.0)\end{array}$ & $\begin{array}{l}115 \\
(38)\end{array}$ & -50 & $\begin{array}{l}154 \\
(16)\end{array}$ & $\begin{array}{r}18.5 \\
(.2)\end{array}$ \\
\hline Day 7 & $\begin{array}{l}70 \\
(3)\end{array}$ & $\begin{array}{c}.501 \\
(.153)\end{array}$ & $\begin{array}{l}169 \\
(71)\end{array}$ & 104 & $\begin{array}{l}83.5 \\
(6.5)\end{array}$ & $\begin{array}{l}14.7 \\
(1.1)\end{array}$ \\
\hline Day 14 & $\begin{array}{c}75 \\
(21)\end{array}$ & $\begin{array}{r}.264 \\
(.367)\end{array}$ & $\begin{array}{l}142 \\
(44)\end{array}$ & 37 & $\begin{array}{l}62.8 \\
(7.5)\end{array}$ & $\begin{array}{l}6.46 \\
(.43)\end{array}$ \\
\hline \multicolumn{7}{|c|}{ Bay 10 Simulation $\left(0.5,5.0,0.2 \mathrm{mg} \cdot \mathrm{kg}^{-1}\right)$} \\
\hline$\overline{0}$ & $\begin{array}{c}71 \\
(32)\end{array}$ & $\begin{array}{l}1.05 \\
(.68)\end{array}$ & $\begin{array}{l}130 \\
(22)\end{array}$ & $\begin{array}{c}359 \\
(408)\end{array}$ & $\begin{array}{c}53.1 \\
(34.4)\end{array}$ & $\begin{array}{c}7.88 \\
(3.88)\end{array}$ \\
\hline $18 \mathrm{~h}$ & $\begin{array}{c}100 \\
(0)\end{array}$ & $\begin{array}{c}.504 \\
(.647)\end{array}$ & $\begin{array}{l}176 \\
(64)\end{array}$ & 176 & $\begin{array}{c}23.3 \\
(10.5)\end{array}$ & $\begin{array}{l}2.68 \\
(.39)\end{array}$ \\
\hline Day 7 & $\begin{array}{c}63 \\
(18)\end{array}$ & $\begin{array}{c}.939 \\
(.490)\end{array}$ & $\begin{array}{c}83 \\
(49)\end{array}$ & 263 & $\begin{array}{c}46.7 \\
(2.2)\end{array}$ & $\begin{array}{l}7.66 \\
(.36)\end{array}$ \\
\hline Day 14 & $\begin{array}{l}78 \\
(6)\end{array}$ & $\begin{array}{c}.996 \\
(.590)\end{array}$ & $\begin{array}{c}41 \\
(30)\end{array}$ & 370 & $\begin{array}{c}60.1 \\
(15.9)\end{array}$ & $\begin{array}{r}11.0 \\
(.5)\end{array}$ \\
\hline \multicolumn{7}{|l|}{ Control } \\
\hline 0 & $\begin{array}{c}98 \\
(2)\end{array}$ & $\begin{array}{c}2.724 \\
(2.292)\end{array}$ & $\begin{array}{l}132 \\
(67)\end{array}$ & 1272 & $\begin{array}{l}16.8 \\
(0.0)\end{array}$ & $\begin{array}{l}6.88 \\
(.38)\end{array}$ \\
\hline Day 7 & nd & nd & nd & nd & $\begin{array}{l}52.6 \\
(8.1)\end{array}$ & $\begin{array}{r}14.7 \\
(.4)\end{array}$ \\
\hline Day 9 & $\begin{array}{c}89 \\
(10)\end{array}$ & $\begin{array}{c}.772 \\
(.442)\end{array}$ & $\begin{array}{l}158 \\
(67)\end{array}$ & 275 & $\begin{array}{l}18.9 \\
(5.6)\end{array}$ & $\begin{array}{l}2.21 \\
(.76)\end{array}$ \\
\hline Day 13 & $\begin{array}{l}89 \\
(5)\end{array}$ & $\begin{array}{c}.899 \\
(.154)\end{array}$ & $\begin{array}{l}167 \\
(20)\end{array}$ & 329 & $\begin{array}{l}26.7 \\
(7.6)\end{array}$ & $\begin{array}{c}4.69 \\
(.20)\end{array}$ \\
\hline
\end{tabular}

$* t=0$ represents the start of the $18 \mathrm{~h}$ exposure.

nd - No data.

() - standard deviation.

ASSIM - Assimilation (efficiency \%).

FILT - Filtration rate $\left(l \cdot \mathrm{h}^{-1}\right)$.

RESP - Respiration rate $\left(\mu l \mathrm{O}_{2}\right.$ consumed $\left.\cdot \mathrm{h}^{-1}\right)$.

AAT - Aspartate aminotransferase $\left(0.001\right.$ activity units $\cdot \mathrm{mg}$ protein $\left.{ }^{-1} \cdot \mathrm{min}^{-1}\right)$. G6PDH - Glucose-6-phosphate dehydrogenase $(0.001$ activity units $\cdot \mathrm{mg}$ protein ${ }^{-1} \cdot \mathrm{min}^{-1}$ ).

the animal had returned to control levels by the end of the clearance period.

Enzymatic activities of animals exposed to Bay 9 spill conditions had greatly increased following oil exposure but returned to control levels within 14 days. Bay 10 animals, however, experienced a reduction in the activities of both enzymes following exposure to dispersed oil; this activity had returned to control levels within 14 days.

The physiological character of control populations of $S$. groenlandicus changed very little over time; enzyme activity levels remained stable for the first 7 days, while experimental animals had undergone filtration, respiration and enzyme activity rate changes within that period.

\section{Tissue Hydrocarbons}

Petroleum hydrocarbons were present in tissue samples after both experimental exposures (Table 4). After $6 \mathrm{~h}$ exposure to the 18 h-long Bay 9 simulations, tissues of $M$. truncata and $S$. groenlandicus contained similar levels of hydrocarbons, 66 and $60 \mathrm{mg} \cdot \mathrm{kg}^{-1}$ respectively. These levels continued to increase throughout the exposure period, reaching a maximum of 700 $\mathrm{mg} \cdot \mathrm{kg}^{-1}$ after $18 \mathrm{~h}$. Although hydrocarbon levels in tissues of $M$. truncata dropped more rapidly than did those of $S$. groenlandicus during the first 3 days of the clearance period, they 
TABLE 4. Total petroleum ( $\mu \mathrm{g} \cdot \mathrm{g}^{-1}$ wet weight) in Mya truncata, Serripes groenlandicus and Strongylocentrotus droebachiensis from control, Bay 9 and Bay 10 simulations

\begin{tabular}{|c|c|c|c|c|c|c|c|c|}
\hline \multirow[b]{2}{*}{ Series } & \multirow[b]{2}{*}{ Species } & \multirow[b]{2}{*}{$6 \mathrm{~h}$} & \multicolumn{6}{|c|}{ Concentration $^{\mathrm{a}}$ at time of sampling } \\
\hline & & & $18 \mathrm{~h}^{\mathrm{b}}$ & $36 \mathrm{~h}$ & $3 \mathrm{~d}$ & $7 \mathrm{~d}^{\mathrm{b}}$ & $14 \mathrm{~d}$ & $21 \mathrm{~d}$ \\
\hline Control $^{c}$ & $\begin{array}{l}\text { Mya } \\
\text { Serripes } \\
\text { Strongylocentrotus }\end{array}$ & $\frac{-}{-}$ & $\begin{array}{c}2.0 \pm 0.7 \\
3.7 \pm 0.2 \\
1.0\end{array}$ & - & 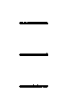 & $\begin{array}{l}2.3 \pm 0.9 \\
3.3 \pm 0.3 \\
1.0 \pm 0\end{array}$ & $\begin{array}{l}1.0 \\
0.46 \\
0.52\end{array}$ & $\begin{array}{l}0.62 \\
3.6 \\
1.0\end{array}$ \\
\hline \multicolumn{9}{|l|}{1982} \\
\hline Bay $9^{(\mathrm{cv})}$ & $\begin{array}{l}\text { Mya } \\
\text { Serripes } \\
\text { Strongylocentrotus }\end{array}$ & & $\begin{array}{r}540 \\
99 \\
61\end{array}$ & & & $\begin{array}{l}340 \\
170.0 \\
380\end{array}$ & & \\
\hline Bay $9^{c}$ & $\begin{array}{l}\text { Mya } \\
\text { Serripes } \\
\text { Strongylocentrotus }\end{array}$ & & $\begin{array}{l}600 \pm 21.2 \\
695 \pm 116.7 \\
135 \pm 10.6\end{array}$ & & & $\begin{array}{c}47 \pm 0 \\
91.5 \pm 41.4 \\
430 \pm 56.6\end{array}$ & & \\
\hline Bay 10 & $\begin{array}{l}\text { Mya } \\
\text { Serripes } \\
\text { Strongylocentrotus }\end{array}$ & & $\begin{array}{r}16 \\
130 \\
21\end{array}$ & & & $\begin{array}{r}45 \\
22 \\
220\end{array}$ & & \\
\hline \multicolumn{9}{|l|}{1983} \\
\hline$\overline{\text { Bay } 9}$ & $\begin{array}{l}\text { Mya } \\
\text { Serripes } \\
\text { Strongylocentrotus }\end{array}$ & $\begin{array}{r}65.9 \\
60.3 \\
1.7\end{array}$ & $\begin{array}{r}112 \\
25.2 \\
1.0\end{array}$ & $\begin{array}{c}48.8 \\
115 \\
3.3\end{array}$ & $\begin{array}{l}35.8 \\
89.0 \\
16.0\end{array}$ & $\begin{array}{r}12.6 \\
17.6 \\
9.2\end{array}$ & - & $\begin{array}{r}10.1^{\mathrm{b}} \\
5.0^{\mathrm{b}} \\
3.0^{\mathrm{b}}\end{array}$ \\
\hline Bay 10 & $\begin{array}{l}\text { Mya } \\
\text { Serripes } \\
\text { Strongylocentrotus }\end{array}$ & $\begin{array}{r}13.1 \\
13.0 \\
1.4\end{array}$ & $\begin{array}{r}30.9 \\
50.4 \\
1.0\end{array}$ & $\begin{array}{r}18.8 \\
42.4 \\
1.9\end{array}$ & $\begin{array}{r}18.9 \\
15.6 \\
1.8\end{array}$ & $\begin{array}{r}7.1 \\
21.2 \\
1.0\end{array}$ & - & $\begin{array}{r}6.6^{\mathrm{b}} \\
22.1^{\mathrm{b}} \\
1.0^{\mathrm{b}}\end{array}$ \\
\hline
\end{tabular}

${ }^{a}$ Analyses by UV fluorescence (except as noted $b$ by gas chromatography).

${ }^{\mathrm{b}}$ Analyses by gas chromatography.

cAverage values ( \pm standard error) measured by gas chromatography ( $\mathrm{N}=6$ or less).

${ }^{\mathrm{c}}$ Tank covered by sheet glass.

decreased to $10 \mathrm{mg} \cdot \mathrm{kg}^{-1}$ or less in both bivalves within 21 days. Exposure to the lower concentrations of the Bay 10 simulation resulted in a similar pattern of accumulation in both bivalves. However, after 21 days of clearance, $\boldsymbol{M}$. truncata tissues retained hydrocarbon levels of $7 \mathrm{mg} \cdot \mathrm{kg}^{-1}$, whereas $S$. groenlandicus tissues contained $22 \mathrm{mg} \cdot \mathrm{kg}^{-1}$.

As compared to the filter-fecding bivalves, hydrocarbon uptake in $S$. droebachiensis during the Bay 9 exposures was delayed. During the 1982 Bay 9 simulations, hydrocarbon levels in urchins were $135 \mathrm{mg} \cdot \mathrm{kg}^{-1}$ at the end of the $18 \mathrm{~h}$ exposure period and $430 \mathrm{mg} \cdot \mathrm{kg}^{-1}$ by 7 days. Levels attained in tissues of urchins exposed to the Bay 10 simulation were substantially less, reaching $220 \mathrm{mg} \cdot \mathrm{kg}^{-1}$ at day 7 . In the 1983 Bay 9 simulation experiment uptake was slower, with a maximum of $16 \mathrm{mg} \cdot \mathrm{kg}^{-1}$ reported at day 3 in $S$. droebachiensis. Levels decreased to near control by 21 days. The gas chromatographic analysis of tissues from $S$. droebachiensis exposed to the 1983 Bay 10 simulation revealed the presence of only trace amounts of petroleum aromatics, and no significant overall uptake of oil was evident.

No petroleum was detected in any of the control animals by UV fluorescence (detection limit of $0.5 \mathrm{mg} \cdot \mathrm{kg}^{-1}$ ), while gas chromatographic traces revealed only the presence of biogenic hydrocarbon components. Tissues of all three species were analyzed by $\mathrm{GC} / \mathrm{MS}$ for the presence of individual aromatic hydrocarbons and revealed trace levels, $1-3 \mathrm{ng} \cdot \mathrm{g}^{-1}$ of phenanthrene and methylphenanthrene.

Saturated hydrocarbon weathering (SHW), alkane/isoalkane (ALK/ISO) and phytane/ $n$ - $\mathrm{C}_{18}$ ratios (effectively biodegradation ratios) were calculated from the gas chromatographic data. The pristane/phytane ratios (indicating the amount of biogenic pristane present relative to the petrogenic phytane) were also calculated (Table 5). Although changes in hydrocarbon compositional ratios occurred in all species following exposure, they are particularly evident in the bivalves. The SHW ratio in $M$. truncata and $S$. groenlandicus tissues increased with oil exposure and reached maximal levels at the end of the $18 \mathrm{~h}$ sequential exposure. The ALK/ISO ratios decreased from the 18 $\mathrm{h}$ maxima to low values by day 21 of the clearance period.

Pristane/phytane ratios were markedly lower in tissues of both bivalves than they were in the controls following exposure to dispersed oil. This level was maintained throughout the clearance period. Conversely, the phytane $/ n-\mathrm{C}_{18}$ ratio showed a strong increase, but only in the 7 and $21 \mathrm{~d}$ samples taken during the clearance period. Gas chromatographic analysis of $M$. truncata exposed to the Bay 9 simulation indicated that relatively unweathered (SHWR $=1.7$ ) undegraded (ALK/ISO = $1.9, \mathrm{Phy} / \mathrm{C}_{18}-0.65$ ) oil was found in the tissue at the end of the exposure period $\mathrm{t}=18 \mathrm{~h}$. Fractional analysis of oil in $S$. groenlandicus during this period indicates that the saturated and aromatic components were more substantially weathered. Weathering and degradation of the petroleum components was evident at days 7 and 21 with the increase in ALK/ISO and decrease in $\mathrm{Phy} / \mathrm{C}_{18}$ ratios.

Both aromatic and saturated hydrocarbons were taken up in approximately equal amounts by the bivalves exposed to the Bay 9 and Bay 10 simulations (Table 5). In 1982 hydrocarbon accumulation in $S$. droebachiensis continued to increase into the post-exposure period (Table 4) clearance period. This accumulation was characterized by a preferential uptake of the aromatic fraction. The 1983 data for urchins yield no interpretable results because of the low hydrocarbon uptake. Aromatic hydrocarbon initially acquired and retained by both bivalves at $18 \mathrm{~h}$ consisted of large quantities of alkylated benzenes and naphthalenes. The lighter aromatic fraction was subsequently depurated, leaving alkylated naphthalene, phenanthrene and dibenzothiophene 
TABLE 5. Petroleum hydrocarbon fractions (1983) in tissues of Mya truncata, Serripes groenlandicus and Strongylocentrotus droebachiensis from control, Bay 9 and Bay 10 simulations

\begin{tabular}{|c|c|c|c|c|c|c|c|c|}
\hline \multirow[b]{2}{*}{ Sample } & & \multicolumn{3}{|c|}{ Concentration } & \multicolumn{4}{|c|}{ Ratio } \\
\hline & & $\begin{array}{c}f_{1} \\
\left(\mu g \cdot g^{-1} \text { wet }\right) \\
\end{array}$ & $\begin{array}{c}f_{2} \\
\left(\mu g \cdot g^{-1} \text { wet }\right) \\
\end{array}$ & $\begin{array}{c}\text { Total } \\
f_{1} \& f_{2} \\
\left(\mu g \cdot g^{-1} \text { wet }\right) \\
\end{array}$ & SHWR & ALK/ISO & Pris/Phy & Phy $/ n-\mathrm{C}_{18}$ \\
\hline \multirow[t]{9}{*}{ Control* } & Mya & & & & & & & \\
\hline & $18 \mathrm{~h}$ & $<1.2$ & $<1.2$ & $<2.0$ & - & - & 60 & - \\
\hline & $7 \mathrm{~d}$ & $<2$ & $<1.2$ & $<2.8$ & 1.0 & - & $>107$ & 0.62 \\
\hline & Serripes & & & & & & & \\
\hline & $18 \mathrm{~h}$ & $<2.6$ & $<1$ & $<3$ & - & - & 55 & - \\
\hline & $7 \mathrm{~d}$ & $<1.8$ & $<1$ & $<2.3$ & - & - & 34 & - \\
\hline & Strongylocentrotus & & & & & & & \\
\hline & $18 \mathrm{~h}$ & $<1$ & $<1$ & $<1$ & - & - & 125 & - \\
\hline & $7 \mathrm{~d}$ & $<1$ & $<1$ & $<1$ & - & - & 62 & - \\
\hline \multirow{12}{*}{$\begin{array}{l}\text { Bay } 9 \\
(10,100,5)\end{array}$} & Mya & & & & & & & \\
\hline & $18 \mathrm{~h}$ & 62.2 & 50 & 112.0 & 1.7 & 1.9 & 1.2 & 0.65 \\
\hline & $7 \mathrm{~d}$ & 6.4 & 6.2 & 12.6 & 1.1 & 0.40 & 0.27 & 2.6 \\
\hline & $21 \mathrm{~d}$ & 3.4 & 6.7 & 10.1 & 1.1 & - & 0.25 & 2.7 \\
\hline & Serripes & & & & & & & \\
\hline & $18 \mathrm{~h}$ & 13.1 & 12.1 & 25.2 & 1.1 & 1.4 & 1.7 & 0.65 \\
\hline & $7 d$ & 11.5 & 6.1 & 17.6 & 1.1 & 0.13 & 2.6 & 7.4 \\
\hline & $21 \mathrm{~d}$ & 4.1 & 1.0 & 5.0 & 1.1 & 0.10 & 16.2 & 1.0 \\
\hline & Strongylocentrotus & & & & & & & \\
\hline & $18 \mathrm{~h}$ & 1.0 & 1.0 & 2.0 & - & - & 61 & - \\
\hline & $7 \mathrm{~d}$ & 1.0 & 8.2 & 9.2 & - & - & 113 & - \\
\hline & $21 \mathrm{~d}$ & $\sim 1.0$ & 2.0 & $\sim 3.0$ & - & - & 170 & 1.4 \\
\hline \multirow{12}{*}{$\begin{array}{l}\text { Bay } 10 \\
(0.5,2.0,0.2)\end{array}$} & Mya & & & & & & & \\
\hline & $18 \mathrm{~h}$ & 15.3 & 15.6 & 30.9 & 1.5 & 1.5 & 2.0 & 0.69 \\
\hline & $7 \mathrm{~d}$ & 3.0 & 4.1 & 7.1 & - & - & 10.0 & 3.0 \\
\hline & $21 \mathrm{~d}$ & 2.8 & 3.8 & 6.6 & 1.6 & 0.21 & 8.9 & 2.8 \\
\hline & Serripes & & & & & & & \\
\hline & $18 \mathrm{~h}$ & 31.4 & 19.0 & 50.4 & 1.8 & 1.8 & 1.3 & 0.69 \\
\hline & $7 \mathrm{~d}$ & 11.7 & 9.5 & 21.2 & 1.0 & 0.25 & 2.5 & 10.1 \\
\hline & $21 \mathrm{~d}$ & 9.8 & 12.3 & 22.1 & 1.2 & 0.14 & 3.0 & 8.2 \\
\hline & Strongylocentrotus & & & & & & & \\
\hline & $18 \mathrm{~h}$ & $<1$ & $<1$ & $\sim 1.0$ & - & - & 120 & - \\
\hline & $7 \mathrm{~d}$ & $<1$ & $<1$ & $\sim 1.0$ & - & - & 160 & - \\
\hline & $21 \mathrm{~d}$ & $<1$ & $<1$ & $\sim 1.0$ & - & - & 85 & - \\
\hline
\end{tabular}

$-=$ No data because of inability to resolve, due to low concentration of hydrocarbons.

*Average of two controls.

$\mathrm{f}_{1}$ - Saturated hydrocarbon fraction.

$\mathrm{f}_{2}$ - Aromatic hydrocarbon fraction.

SHWR - Saturated hydrocarbon weathering ratio.

ALK/ISO - Ratio of $n$-alkanes to isoprenoid alkanes.

Pris/Phy - Ratio of pristane to phytane.

Phy $/ n-C_{18}$ - Ratio of phytane to $n-C_{18}$.

components. Similar compositional trends were detected in tissues of the test species exposed to the Bay 10 simulation. However, after $21 \mathrm{~d}$, substantial quantities of light aromatics (alkyl benzene and naphthalene components) remained in $S$. groenlandicus at $21 \mathrm{~d}$, as compared to the Bay 9 animals and to $M$. truncata from Bay 10.

$S$. groenlandicus exposed to the higher concentration of the Bay 9 test interrupted filtration activity prior to $18 \mathrm{~h}$, whereas filtration activity during the Bay 10 simulation was not interrupted and body burdens continued to increase during the exposure period (Table 6). The difference in filtration activity is further reflected by the exponential regression analysis, which clearly indicates a high degree of interdependence between SFG, AAT and G-6-PDH in S. groenlandicus with body burden of aromatic hydrocarbons in the Bay 10 simulation.

Both 1981 field data (Boehm et al., 1982b) and 1983 tank experiment data are presented in Table 7.

The patterns of hydrocarbon accumulation and release
TABLE 6. Relationship between filtration rate, hydrocarbon uptake and hydrocarbon depuration in Serripes groenlandicus

\begin{tabular}{lcccc}
\hline \hline & Time & $\begin{array}{c}\text { Filtration } \\
\text { rate }\end{array}$ & $\begin{array}{c}\text { Hydrocarbon } \\
\text { burden } \\
\left(\mu \mathrm{g} \cdot \mathrm{g}^{-1}\right. \\
\text { wet weight) }\end{array}$ & $\begin{array}{c}\text { Hydrocarbon } \\
\text { (halflife) } \\
\text { depuration }\end{array}$ \\
\hline Bay 9 $\left(10,100,5 \mathrm{mg} \cdot \mathrm{kg}^{-1}\right)$ & 0 & $1.05^{\mathrm{a}}$ & - & \\
& $18 \mathrm{~h}$ & 0.00 & 25.2 & \\
$7 \mathrm{~d}$ & 0.501 & 17.5 & \\
$14 \mathrm{~d}$ & 0.264 & - & \\
$21 \mathrm{~d}$ & - & 5.0 & $8.41 \mathrm{~d}$ \\
Bay $10\left(0.5,5.0,0.2 \mathrm{mg} \cdot \mathrm{kg}^{-1}\right.$ & & & \\
& 0 & $1.05^{\mathrm{a}}$ & - & \\
$18 \mathrm{~h}$ & 0.504 & 50.4 & \\
$7 \mathrm{~d}$ & 0.939 & 21.2 & \\
$14 \mathrm{~d}$ & 0.996 & - & $21.0 \mathrm{~d}$ \\
$21 \mathrm{~d}$ & - & 22.1 & \\
\hline
\end{tabular}

Mean filtration rate in $l \cdot h^{-1}$ for standard animals not exposed to oil. 
TABLE 7. Comparison of tissue hydrocarbons from 1981 field results with 1983 experimental results

\begin{tabular}{|c|c|c|c|}
\hline \multirow[b]{2}{*}{ Species } & \multicolumn{3}{|c|}{$\begin{array}{l}\text { Tissue concentrations } \\
\text { (mg } \cdot \mathrm{kg}^{-1} \text { net weight) }\end{array}$} \\
\hline & Sample time* & Bay 9 & Bay 10 \\
\hline \multicolumn{4}{|l|}{ Mya } \\
\hline & $\begin{array}{l}18 \mathrm{~h} \\
1-4 \mathrm{~d} \text { (field) } \\
7 \mathrm{~d} \\
14 \mathrm{~d} \text { (field) } \\
21 \mathrm{~d}\end{array}$ & $\begin{array}{l}112 \\
17-31 \\
13 \\
16-19 \\
10\end{array}$ & $\begin{array}{l}31 \\
40-53 \\
7 \\
19-22 \\
7\end{array}$ \\
\hline \multicolumn{4}{|l|}{ Serripes } \\
\hline & $\begin{array}{l}18 \mathrm{~h} \\
1-4 \mathrm{~d} \text { (field) } \\
7 \mathrm{~d} \\
14 \mathrm{~d} \text { (field) } \\
21 \mathrm{~d}\end{array}$ & $\begin{array}{l}25 \\
26-70 \\
18 \\
13-23 \\
5\end{array}$ & $\begin{array}{l}50 \\
40-47 \\
21 \\
20-25 \\
22\end{array}$ \\
\hline
\end{tabular}

*18 h, 7 d, 21 d; 1983 laboratory simulations (this study).

(field) - 1-4 d, $14 \mathrm{~d}$ field derived (from Boehm et al., 1982b).

Note: Data quoted have not been adjusted to account for postulated $10-20 \%$ difference in total hydrocarbon concentration between $\mathrm{GC}^{2}$ and $\mathrm{UV}$ fluorescence analytical results.

observed in the tanks reflect those observed during the field spill. When the results are ordinated in a time sequence irrespective of the field or laboratory origin, a clear trend for depuration over time is apparent.

\section{DISCUSSION}

\section{Behavioural and Physiological Responses}

The results of the behavioural, metabolic and biochemical components of this study support the summary conclusion of the BIOS field program, namely, that "the use of chemical dispersants in coastal areas [arctic] can be an environmentally acceptable counter-measure" (Sergy, 1986:22). The two-year post-spill monitoring program did not detect large-scale mortality of benthic biota in the field or any significant changes in infaunal community structures (Cross and Thomson, 1987). The present study has indicated that the sharp increase in water-soluble and dispersed hydrocarbons that resulted from the application of dispersants produced an immediate but shortterm effect on the subtidal benthos. This exposure temporarily affected behavioural and physiological functions, but recovery occurred within two weeks for the most part.

Behavioural responses of the bivalves exposed to Bay 9 and Bay 10 simulations confirmed the range and intensity of behavioural effects recorded by divers during the 1981 field spill (Cross and Thomson, 1981). M. truncata and $S$. groenlandicus initially responded to the apparently noxious stimulus of dispersed oil from the Bay 10 simulation by rapid ostial closure. This temporary response offered the bivalves a short-term survival advantage by arresting water flow, filtration and therefore oil input. This ability to interrupt filtration, the loss of response to mechanical stimuli and the onset of narcosis have been documented for a number of bivalves (Hargrave and Newcombe, 1973; McManus and Connel, 1972). Percy and Mullin (1975) observed a similar suspension and later resumption of feeding activity in Yoldiella intermedia and postulated a direct dose-response relationship between the concentration of oil and the duration of the interruption.

$S$. groenlandicus exposed to the Bay 9 conditions suspended filtration activity and consequently accumulated less hydrocarbon in their tissue than did the bivalves exposed to the Bay 10 simulations, which continued to filter (Table 6). A lower filtration rate of $0.204 l \cdot h^{-1}$ reported by Gilfillan and Vallas (1984) may serve to minimize hydrocarbon uptake in $M$. truncata as compared to $S$. groenlandicus, which has a markedly higher baseline filtration rate. While the rate of hydrocarbon accumulation uptake is dependent upon the clearance rate, the relationship between the filtration and depuration rates is less clear.

Emergence from the sediment was the only behavioural response noted during the exposure to the lower hydrocarbon levels of the Bay 10 simulation. This response, shell and mantle gape and narcosis were predominant in $S$. groenlandicus during the latter phases of the Bay 9 simulation. These stress-induced responses and the exposure of soft mantle tissue resulting from shell damage and narcosis may be of importance to the survival potential of the bivalve in the field. This susceptibility to predation would be compounded by the bivalve's inability to respond to tactile stimuli, further limiting normal escape responses. It is probable, however, that in a real spill situation these narcosis-like responses would be short lived, as evidenced by the situation reported in Bays 9 and 10 following the 1981 field spill at Cape Hatt (Cross and Thomson, 1987). Similarly the Searsport experiment (Gilfillan et al., 1984) did not report lasting physiological effects caused by the dispersed oil spill. It is not possible to compare the sensitivity of the Searsport organisms Mya arenaria and Mytilus edulis to $M$. truncata and S. groenlandicus. No samples were taken at Searsport prior to 7 days post-spill, whereas the major effects noted during the BIOS spill simulations were observed within 2 days.

The stress-related behavioural changes observed in $S$. groenlandicus exposed to the Bay 9 simulation corresponded to disruption of metabolic functions, including a reduction of carbon flux, an increase in respiration rate, changes in enzyme activities and the interruption of filtration activities. Although not critical to immediate survival, these physiological alterations, combined with the oil toxicity, are thought to impair natural survival potential of bivalves in areas of low food availability (Thomas, 1977).

Work by Dunning and Major (1974) documented the stimulation of metabolic functions in Mytilus edulis chronically exposed to selected oil fractions. Demonstrated effects included a pronounced negative energy balance as well as a significant reduction in shell growth, tissue weight, nutrient storage and gonadal development. Although not all of these effects were noted during this study, significant reductions in scope for growth of S. groenlandicus were recorded during the Bay 9 and Bay 10 simulations. Comparison of SFG results for $S$. groenlandicus exposed to the greater exposure of the Bay 9 simulation with those from the Bay 10 simulation indicate a twofold reduction in the scope for growth.

Evidence of in vivo biodegradation of petroleum residues was noted in bivalve tissues in these tank simulations, confirming Boehm et al.'s (1982b) earlier hypothesis concerning the retention of hydrocarbons in the gut of Cape Hatt bivalves and their rapid biodegradation. There is no conclusive evidence to determine whether this biodegradation was mediated by microflora in the gut of the animal as opposed to active metabolism by the animals themselves.

The reliance of echinoderms on a water-vascular system and their omnivorous feeding habit make them susceptible to both 
water-borne and sediment-borne contaminants. Yet, few studies have examined their physiological and metabolic responses to oil exposure. North et al. (1964) reported tube foot debilitation in urchins exposed to low hydrocarbon concentration, while Yentsch et al. (1973) reported increased respiration rates in $S$. droebachiensis exposed to crude oil extracts.

The rapid distribution of hydrocarbons by the water vascular system would generalize the narcotic effects of hydrocarbons to cause behavioural inhibition of tube feet and spines. Although interruption of water flow was not verified, tube feet changes alone suggest ultimate impairment of the hydrostatic system. Altered spinal attitude consisting of spine droop or spine rigidity was noted during both simulations and is indicative of a neuromuscular effect initially narcotic in nature. While spine droop may increase damage potential and predation, spine rigidity is believed to counter that effect but at the same time enhance the potential for physical displacement by currents. The spine control system and responsiveness to stimuli recovered more quickly than did the tube foot responses, which also suggests that two different physiological systems were affected by exposure to oil.

Behavioural responses of $S$. droebachiensis to the sequential dosing correlated well with divers' observations of the urchins at the site of the BIOS spill. Loss of adherence, narcotization, free passive displacement in currents and a decrease in the number of individuals in the spill area were all reported at that time. The natural repercussion of the early loss and slow recovery of tube foot functions could include increased susceptibility to predation, physical damage and removal from habitat and food sources. An additional behavioural effect related to the hydrocarbon narcosis was noted by Rice et al. (1983) in echinoderms that failed to respond to chemicals released by prey.

\section{Hydrocarbon Uptake}

Differential uptake of hydrocarbons was apparent among the species; $M$. truncata and $S$. groenlandicus retained both the aromatic and saturated compounds but quickly depurated the lighter aromatics. The urchin, however, preferentially retained aromatic fractions of petroleum and released the saturated compounds. Early differential uptake of volatile hydrocarbons such as water-soluble alkyl benzenes by $S$. droebachiensis are thought to result in the initial narcosis and debilitation of tube foot functions. Unlike the bivalves, however, urchin tissues continued to accumulate hydrocarbons long beyond the $18 \mathrm{~h}$ exposure period. The source of these hydrocarbons is thought to be the accumulated residue on the urchin test, which probably was taken up throughout exposure and recovery periods. This continued uptake may serve to explain the delayed mortality of oil-exposed urchins observed in other experiments testing higher levels of oil exposure (Mageau and Engelhardt, 1984; Engelhardt et al., 1984).

Differences were noted in behavioural responses and in hydrocarbon uptake patterns of $S$. droebachiensis sampled in 1982 and 1983 as related to the "spine rigidity" index and tissue hydrocarbon levels. These differences in hydrocarbon uptake trends may be related to a difference in reproductive maturity among years. Shedding and fully ripe gonads were observed in the 1982 experimental animals, collected in August-September, indicating that the population was tested during its spawning cycle. Diver reports confirm a May spawing cycle in 1981, but no definitive statement can be made as to the 1983 population.
Gonadal tissue, known to absorb and retain high levels of hydrocarbon (Stegeman and Teal, 1973), was, however, undeveloped in 1983 urchins. Therefore the non-gonadal soft tissue of $S$. droebachiensis constituted a relatively poor reservoir for hydrocarbons.

\section{CONCLUSION}

Behavioural responses indicate that $M$. truncata is tolerant of some exposure to dispersed oil in spite of increased hydrocarbon body burdens. Behavioural changes were marked in $S$. groenlandicus exposed to both Bay 9 and 10 laboratory simulations, that is, both high and low exposure levels. Metabolic functions and hydrocarbon uptake appeared to be related to exposure levels. Suspension of filtration activity, emergence from burial in sediment, heavy body burdens of hydrocarbon and narcotization are all likely to have a short-term effect on the potential for survival and physiological equilibrium of the individual animal.

The urchin $S$. droebachiensis was the most overtly affected of the three species. Temporary impairment of the water vascular system, of the neuro-vascular system and narcotization were the most significant behavioural/physiological disruptions during both Bay 9 and 10 spill simulations. It is expected that these debilitating effects would impact an oiled urchin community only for a short time.

\section{ACKNOWLEDGEMENTS}

The authors recognize the contributions of a number of contractors who assisted in the collection and hydrocarbon and statistical analysis of the 1982 and 1983 data. R. Trucco participated in both experimental programs. B. Stacey was responsible for the data reduction and statistical analysis. D. Vallas participated in the 1983 metabolic work. Sample collection in the field was carried out by divers from LGL Ltd.

This study was made possible by the continued financial support of the Northern Affairs Program of DIAND. Logistic support for the study was provided through the budget of the BIOS Project.

\section{REFERENCES}

ANSELL, A.D., and LANDER, K.F. 1967. Studies on the hard shell clam, Venus mercenaria, in British waters. III. Further observations on the seasonal biochemical cycle and on spawning. Journal of Applied Ecology 4:425-435.

BOEHM, P.D., FIEST, D.L., and HIRTZER, P. 1982a. Chemistry: 2. Analytical biogeochemistry 1981 study results. (BIOS) Baffin Island Oil Spill Working Report 81-2. Ottawa: Environmental Protection Service, Environment Canada. $354 \mathrm{p}$.

, SCOTT, L., NORSTROM, R., and ENGELHARDT, F.R. 1982b. A biogeochemical assessment of the BIOS experiment spills: Transport pathways and fates of petroleum in benthic animals. In: Proceedings of the Fifth Arctic Marine Oil Spill Program Technical Seminar, June 1982, Edmonton, Alberta. 581-618.

BUCKLEY, J.R., DE LANGE BOOM, B.R., and REIMER, E.M. 1987. The physical oceanography of the Cape Hatt Region, Eclipse Sound, N.W.T. Arctic 40 (Supp. 1):20-33.

CRETNEY, W.J., GREEN, D.R., FOWLER, B.R., HUMPHREY, B., ENGELHARDT, F.R., NORSTROM, R.J., SIMON, M., FIEST, D.L., and BOEHM, P.D. 1987. Hydrocarbon biogeochemical setting of the Baffin Island Oil Spill experimental sites. III. Biota. Arctic 40 (Supp. 1):71-79.

CROSS, W.E., and THOMSON, D.H. 1981. Macrobenthos - 1980 study results. (BIOS) Baffin Island Oil Spill Working Report 80-3. Ottawa: Environmental Protection Service, Environment Canada. 81 p.

1987. Effects of experimental releases of oil and dispersed oil on arctic nearshore macrobenthos. I. Infauna. Arctic 40 (Supp. 1):184-200.

DICKINS, D.F., THORNTON, D.E., and CRETNEY, W.J. 1987. Design and operation of oil discharge systems and characteristics of oil used in the Baffin Island Oil Spill Project. Arctic 40 (Supp. 1):100-108. 
DUNNING, A., and MAJOR, C.W. 1974. The effects of cold seawater extracts of oil fractions upon the blue mussel, Mytilus edulis. In: Vernberg, F.J., and Vernberg, W.B., eds. Pollution and Physiology of Marine Organisms. New York: Academic Press. 349-366.

ENGELHARDT, F.R., MAGEAU, C., and TRUCCO, R. 1983. Behavioural responses of benthic invertebrates exposed to dispersed crude oil. Proceedings Arctic Marine Oilspill Technical Seminar, June 1983, Edmonton, Alberta. 32-51.

ENGELHARDT, F.R., MAGEAU, C., GILFILLAN, E., and BOEHM, P.D. 1984. Effects of acute and long term exposure to dispersed oil in benthic invertebrates. Proceedings Arctic Marine Oilspill Technical Seminar, June 1984, Calgary, Alberta. 367-392.

GILFILLAN, E.S., and VALLAS, D.L. 1984. Observation of scope for growth, aspartate aminotransferase activity and glucose-6-phosphate dehydrogenase activity in Mya truncata and Serripes groenlandicus exposed to various concentrations of chemically dispersed crude - 1983 study results. (BIOS) Baffin Island Oil Spill Working Report 83-7. Ottawa: Environmental Protection Service, Environment Canada. 55 p.

GILFILLAN, E.S., MAYO, D., HANSON, S., DONOVAN, D., and JIANG, L.C. 1976. Reduction in carbon flux in Mya arenaria caused by a spill of no. 6 fuel oil. Marine Biology 37:115-123.

GILFILLAN, E.S., MAYO, D.W., PAGE, D.S., DONOVAN, D., and HANSON, S.A. 1977. Effects of varying concentrations of hydrocarbons in sediments on carbon flux in Mya arenaria. In: Vernberg, F.J., Calabrese, A., Thurberg, F.P., and Vernberg, W.B., eds. Physiological Responses of Marine Biota to Pollutants. New York: Academic Press. 299-314.

GILFILLAN, E.S., PAGE, D.S., HANSON, S.A., FOSTER, J., HOLMAN, J., VALLAS, D., and GERBER, R. 1984. Effects of test spills of chemically dispersed and non-dispersed oil on the activity of aspartate aminotransferase and glucose-6-phosphate dehydrogenase activity in two intertidal bivalves, Mya arenaria and Mytilus edulis. In: Allen, T.E., ed. Oil Spill Chemical Dispersants: Five Years of Research. ASTM, Special Technical Publication 840:299-313.

GOULD, E. 1977. Alteration of enzymes in winter flounder, Pseudopleuronectes americanus, exposed to sublethal amounts of cadmium chloride. In: Vernberg, F.J., Calabrese, A., Thurberg, F.P., and Vernberg, W.B., eds. Physiological Responses of Marine Biota to Pollutants. New York: Academic Press. 209-224.

GREEN, D.C., HUMPHREY, B., and FOWLER, B. 1982. Baffin Island Oil Spill project; Chemistry component, report on the 1981 oil spill experiments. Vol. 1, Summary of field work. (BIOS) Baffin Island Oil Spill Working Report 81-1. Ottawa: Environmental Protection Service, Environment Canada. $111 \mathrm{p}$.

HARGRAVE, B.T., and NEWCOMBE, C.P. 1973. Crawling and respiration as indices of sublethal effects of oil and dispersant on an intertidal snail,
Littorina littorea. Journal of Fisheries Research Board of Canada 30:1789-1792.

HUMPHREY, B., BOEHM, P.D., HAMILTON, M.C., and NORSTROM, R.J. 1987. The fate of chemically dispersed and untreated crude oil in arctic benthic biota. Arctic 40 (Supp. 1):149-161.

MAGEAU, C., and ENGELHARDT, F.R. 1984. Behavioural and physiological effects of hydrocarbon exposure on selected arctic invertebrates. (BIOS) Baffin Island Oil Spill Working Report 83-7. Ottawa: Environmental Protection Service, Environment Canada. 67 p.

MCMANUS, D.A., and CONNEL, D.W. 1972. Toxicity of the oil dispersant, Corexit 7664, to certain Australian marine animals. Search 3:222-224.

NORTH, W.J., NEUSHAL, M., and CLENDENNING, K.A. 1964. Biological changes observed in a marine core exposed to a large spillage of mineral oil. In: Symposium sur Pollutions Marines par les Microorganismes et les Produits Pétrolier. Monaco: International Commission for the Scientific Exploration of the Mediterranean Seas. 335-354.

PERCY, J.A., and MULLIN, T.C. 1975. Effects of crude oils on arctic marine invertebrates. Beaufort Sea Project Technical Report 11.167 p.

RICE, S.D., MOLES, D.A., KARINEN, J.F., KORN, S., CARLS, M.G., BRODERSEN, C.C., GHARRETTAND, J.A., and BABCOCK, M.M. 1983. Effects of petroleum hydrocarbons on Alaskan aquatic organisms. A comprehensive review of all oil-effects research on Alaskan fish and invertebrates conducted by the Auke Bay Laboratory, 1970-81. Processed report, Northwest Fisheries Center, Auke Bay Fisheries Laboratory, National Marine Fisheries Service, NOAA, Auke Bay, Alaska. 145 p.

SERGY, G.A. 1986. The Baffin Island Oil Spill Project, Overview Publication. Ottawa: Department of Environment. $26 \mathrm{p}$.

and BLACKALL, P.J. 1987. Design and conclusions of the Baffin Island Oil Spill Project. Arctic 40 (Supp. 1):1-9.

SIEGEL, S. 1956. Non-parametric Statistics for the Behavioural Sciences. McGraw-Hill Series in Psychology. New York: McGraw-Hill. 312 p.

STEGEMAN, J.J., and TEAL, J.M. 1973. Accumulation, release and retention of petroleum hydrocarbons by the oyster Crassostrea virginica. Marine Biology 22:37-44.

THOMAS, M.L.H. 1977. Long term biological effect of Bunker $\mathrm{C}$ oil in the intertidal zone. In: Wolfe, D.A., ed. Fate and Effects of Petroleum Hydrocarbons in Marine Organisms and Ecosystems. 238-245.

THURBERG, F.P., CALABRESE, A., GOULD, E., GREIG, R.A., DAWSON, M.A., and TUCKER, R.K. 1977. Response of the Lobster, Homarus americanus, to sublethal levels of cadmium and mercury. In: Vernberg, F.J., Calabrese, A., Thurberg, F.P., and Vemberg, W.B., eds. Physiological Responses of Marine Biota to Pollutants. New York: Academic Press. 185-198.

YENTSCH, C.S., GILFILLAN, E.S., and SEARS, J.R. 1973. The fate and behaviour of crude oil on marine life. AD-678584. Springfield, Va.: National Technical Information Service, U.S. Department of Commerce. 62 p. 